10.4274/tjps.47108

Research Article

\title{
Evaluation of Anti-inflammatory Activity of Nelumbo nucifera Fruit Ethanol Extract
}

\section{Running Title: Anti-inflammatory Activity of Nelumbo nucifera Fruit}

Muhammad Ali Rajput ${ }^{1 *}$, Tabassum Zehra ${ }^{2}$, Fizzah Ali², Gunesh Kumar ${ }^{3}$

*Department of Pharmacology, Multan Medical \& Dental College, Multan 66000, Pakistan ${ }^{1}$

Department of Pharmacology, Liaquat National Medical College, Karachi, Pakistan ${ }^{2}$

Lecturer department of Pharmacology, Liaquat University of Medical \& Health Sciences, Jamshoro, Sindh, Pakistan ${ }^{3}$

\begin{abstract}
Introduction: Recently use of herbal therapies rich in flavonoids and vitamins have increased substantially to treat inflammatory states and are supposed to be safe and economical as compared to other conventional allopathic drugs. Thus existing research work encircled to appraise the anti-inflammatory activity of Nelumbo nucifera fruit (NNF) for evaluating its traditional use pharmacologically in disorders which are associated with pain and inflammation. Methods: For the assessment of anti-inflammatory activity 35 male Wister rats weighing 180$230 \mathrm{~g}$ were used for carrageenan induced paw edema method and were equally divided in to five treatment groups $(n=7)$. The paw edema was measured using volume displacement method by plethysmometer.
\end{abstract}

Results: The NNF extract highly significantly reduced the paw swallowing and decreased the edema volume in rats which was induced by carrageenan administration at all doses from $3^{\text {rd }}$ to $5^{\text {th }}$ hour as compared to control with maximum percent reduction of edema was calculated at a dose of $100 \mathrm{mg} / \mathrm{kg}$ i.e. $73.92 \%$ at $5^{\text {th }}$ hour after administration of carrageenan.

Conclusion: NNF have exhibited strong anti-inflammatory activity which may be due to the presence of flavonoids, saponins and tannins in it which synergistically exert inhibitory effects on the arachidonic acid metabolism, neutrophil degranulation and on enzyme systems which promote cell growth, proliferation and regulates complement cascade but more preclinical and clinical evaluation is mandatory to approve these results.

Key words: Nelumbo nucifera, flavonoids, carrageenan, arachidonic acid

Muhammad Ali Rajput, Department of Pharmacology, Multan Medical \& Dental College, Multan 66000, Pakistan ${ }^{1}$

drmuhammadali2016@gmail.com

$+923463881721$

0000-0003-3688-8518

10.10.2019

12.12 .2019 


\section{Introduction}

Lots of individuals who experience severe, inexorable and excruciating pain, for instance that resulting from cancer or injury has to rely on morphine, in spite of its established adverse outcomes. Similarly unceasing anti-inflammatory conditions such as rheumatoid arthritis and osteoarthritis are mostly treated with non-steroidal anti-inflammatory drugs (NSAIDS). Although these synthetic agents are dominating the market but issue of toxicity with prolonged use of these agents cannot be ruled out, the most frequent being gastro-intestinal track (GIT) bleeding and ulcers. ${ }^{1,2}$ Hence there is a need to develop new, safe, effective, economical and innocuous analgesics. $^{3}$

The uses of herbal drugs are becoming progressively more popular as they are supposed to be natural, advantageous and lack unwanted effects. ${ }^{4}$ Mostly the plant derived drugs are taken randomly by local population for the treatment of various diseases without having adequate information regarding their usefulness. Hence for proper guidance of the general population, especially users of natural products, there is a need to scientifically prove the effectiveness of these medicinal plants. ${ }^{5}$

Nelumbo nucifera (Lotus), a Nymphaeaceae family plant is commonly cultivated in the hot and humid climatic zones of Thailand, Pakistan, India and China. ${ }^{6}$ Its fruit contains seeds plus pods. The green colored pods offer add-on to the seeds, which are black, hard and ovoid to roundish in shape $\left(1.5 \mathrm{~cm}\right.$ broad and $1.0 \mathrm{~cm}$ long), are organized in whorls. ${ }^{7}$ The seeds are the edible portion and have to be skinned separately before they are eaten.

Its seeds are a wonderful source of protein, fat, asparagines, unsaturated fatty acids and starch. The key active principles exists in seeds are flavonoids, alkaloids, principally liensinine, lotusine, isoliensinine, dauricine, pronuciferine, nuciferine, roemerine, procyanidin, neferine plus armepavine. The seeds also have carbohydrates, gallic acid and isoquininolinol and contain ample amount of various minerals as well for instance potassium, magnesium, calcium, sodium, iron, chromium, manganese, copper and zinc. ${ }^{9,10}$

Recently conducted study on NNF pods has shown the existence of numerous active bioactive principles in them for instance flavonoids, alkaloids, saponins, terpenoids and tannins ${ }^{11}$. Procyanidin (flavonoid) was also squeezed from NNF pods. ${ }^{6}$

Habitually the fruits are used up as a healthy component of Asian cuisine and also as a traditional cure of various ailments e.g. hypertension, palpitation, arrhythmia, fever, pain, inflammation, sleep disorders, chronic diarrhea, spermatorrhea, leucorrhoea, bad breath, leprosy and menorrhagia. ${ }^{12,}{ }^{13}$ Recent research work revealed $\mathrm{LD}_{50}$ value of NNF higher than $5 \mathrm{~g} / \mathrm{kg}$ whereas its neuropharmacological role was also established as an anxiolytic, antidepressant and antiepileptic agent. ${ }^{11,14}$ However very inadequate literature was obtainable concerning its ameliorating effects on inflammation and therefore existing study was centered towards the evaluation of anti-inflammatory activity NNF in order to justify its traditional use pharmacologically in disorders which are connected with pain and inflammation.

\section{Materials and Methods}

Experimental design \& methodology

Research work was executed utilizing the laboratory facilities of Pharmacology department and the Research Institute of Pharmaceutical Sciences, University of Karachi, following approval from the Board of Advance Studies \& Research (BASR) and departmental research \& ethical committee. A population of 35 male Wister rats weighing 180-230 g were used for carrageenan 
induced paw edema method and was equally divided in to five treatment group's i.e. control, reference and 3 test groups.

\section{Animals care}

The research board comprising members of faculty of Pharmacy and Pharmaceutical Sciences, Karachi University (UOK) allowed the use of animals for experiments in accordance with the approach provided by NACLAR and NIH. ${ }^{15}, 16$

The rats were kept in plastic cages with proper preservation of temperature which was kept close to $25^{\circ} \mathrm{C}$ and moistness 50 to $60 \%$ in an alternating twelve hour light and dark cycle. Each mouse was provided access to normal diet and water. The animals were carried to the laboratory about an hour prior to the initiation of experiments. Earlier to dose administration, complete fitness of animals were evaluated throughout the adaptation phase utilizing the laboratory conditions fo seven days chiefly noticing absence of movements, edema, diarrhea and ulceration.

Preparation of extract

After obtaining fruits from domestic fruit bazaar of Hyderabad, Pakistan in July 2015, they were initially presented to department of Pharmacognosy, University of Karachi for identification and authentication and afterwards receipt no NNF-03 was deposited in the same department.

Crude extract was prepared through cold extraction procedure. ${ }^{17}{ }^{18} \mathrm{Six}$ kg fruits were initially rinsed with tap water and the seeds were separated from the pods manually. The seeds have high contents of water that's why they need to be chopped first then left for 06 days for drying out in shade. The dried material obtained was thick so again needs to be ground in to fine powder. In contrast pods were chopped once only and were allowed to dry in shade for just 3 days. The dried pod material takes a coarse powder form. So for better separation and collection of NNF constituents (secondary metabolites) they need to be chopped and dried separately before soaking up together in ethanol $(98 \%)$ for thirty days with occasional shaking.

Afterwards it was sieved using separator (Whatman No. 1). Later it was evaporated using rotary machine under condensed pressure at $40^{\circ} \mathrm{C}$ to $45^{\circ} \mathrm{C}$. The condensed material was freeze dried in a freeze dryer at $-30^{\circ} \mathrm{C}$. The material so gained was preserved at $-20^{\circ} \mathrm{C}$ until further use in doses of 50,100 and $200 \mathrm{mg} / \mathrm{kg}$ orally. The ultimate amount of the extract acquired was $400 \mathrm{~g}$ of dry weight.

\section{Preparation of drugs}

Carrageenan and gum tragacanth were obtained from Merck whereas aspirin was obtained from one of the renowned medical stores in Karachi.

$2 \%$ tragacanth gum in powder form was acquired from Merck which was consumed to make suspensions of 3 different doses of test drug i.e. NNF $50,100 \& 200 \mathrm{mg} / \mathrm{kg}$. It was given to control group as placebo in the dose of $10 \mathrm{ml} / \mathrm{kg}$ orally. $100 \mathrm{ml}$ of warm distilled water was added in $2 \mathrm{~g}$ tragacanth gum to make $2 \%$ suspension. At each occasion new suspensions were prepared for dosing. 19,20

Carrageenan suspension $0.1 \mathrm{ml}$ of $1 \% \mathrm{w} / \mathrm{v}$ prepared in $0.9 \%$ saline, injected under the planter apo neurosis of right hind paw was used to induce hind paw edema in rats. ${ }^{21}$

Aspirin $300 \mathrm{mg}$ tablets were trampled and suspended in gum tragacanth $(2 \%)$ which was then administered to rats in a dose of $150 \mathrm{mg} / \mathrm{kg}$ orally as reference agent with orogastric tube. ${ }^{22}$ Hind paw edema method

It is the widely used method, performed to assess the anti-inflammatory potential of NNF extract by inducing edema in the right hind paw of rat by carrageenan. Generally carrageenan is used as phlogistic agent i.e. a substance that induces inflammation or edema. ${ }^{23}$ 
The test was performed on 35 Wister rats which were equally placed in five groups i.e. $n=7$. One group served as control and was given $2 \%$ gum tragacanth; one group served as reference group and was given aspirin $150 \mathrm{mg} / \mathrm{kg}$ and three groups represented as test groups and were given NNF 50, 100 and $200 \mathrm{mg} / \mathrm{kg}$. All drugs were administered per oral (PO) one hour prior the administration of carrageenan injection. Carrageenan suspension $0.1 \mathrm{ml}$ of $1 \% \mathrm{w} / \mathrm{v}$ prepared in saline was injected under the planter Apo-neurosis of right hind paw of rats and edema was induced. ${ }^{21}$

The paw edema was measured using volume displacement method by plethysmometer (UGO Basile 7140, Italy), which is perhaps the most efficient method to measure anti-inflammatory response of a drug. Plethysmometer is basically a volume meter, composed of water filled Perspex cell in to which hind paw of rat was immersed and the transducer recorded small changes in water level caused by volume displacement and its digital meter displayed the exact volume of water being displaced by edema in hind paw of rats. The swelling was quantified in terms of $\mathrm{ml}$ of edema at different time interval i.e. paw volume prior the administration of carrageenan (time $=0$ baseline) and after 1,2, 3, 4 and 5 hour was noted. The difference in paw volume assessed before and after injection of phlogistic agent points towards the severity of edema. Lastly percent inhibition of paw inflammation was assessed in terms of $\%$ inhibition. ${ }^{24}$ $\%$ Inhibition $=A-B / A \times 100$

Where

$\mathrm{A}=$ the average paw volume for test groups

$\mathrm{B}=$ the average paw volume for control group Statistical analysis

The data was lay open to analysis by taking average and standard error to the average utilizing two sample student $\mathrm{T}$ - test and values of $\mathrm{P}$ less than 0.05 were reflected as significant and P less than 0.005 as extremely significant. All statistical methods were accomplished with SPSS software version 20.

\section{Results}

\section{Hind paw edema method}

Table 1 and 2 demonstrated that the carrageenan injection produced a localized edema at the right hind paw of rats which reached to its maximum at the $3^{\text {rd }}$ hour after carrageenan administration and then gradually reduces after this period. NNF ethanol extract at doses 50, 100 and $200 \mathrm{mg} / \mathrm{kg}$ highly significantly reduced the paw edema volume from $3^{\text {rd }}$ to $5^{\text {th }}$ hour as compared to control with maximum percent reduction in edema was noted at a dose of 100 $\mathrm{mg} / \mathrm{kg}(73.92 \%)$ at $5^{\text {th }}$ hour after administration of carrageenan. The initial phase of the edema i.e. $1^{\text {st }}$ and $2^{\text {nd }}$ hour was not affected by fruit extract. On the other hand aspirin $150 \mathrm{mg} / \mathrm{kg}$ highly significantiy reduced paw edema volume as compared to control from $1^{\text {st }}$ to $5^{\text {th }}$ hour with maximum percent inhibition of edema $(88.17 \%)$ was noted at $5^{\text {th }}$ hour after administration of carrageenan 
Table 1: Anti-inflammatory effect of NNF \& aspirin analyzed through hind paw edema method in rats

\begin{tabular}{|c|c|c|c|c|c|c|c|c|c|c|c|}
\hline \multirow[t]{2}{*}{$\begin{array}{l}\text { Group } \\
\text { s }\end{array}$} & \multicolumn{6}{|c|}{ Average Paw Size $(\mathrm{ml}) \pm$ S.E.M } & \multicolumn{5}{|c|}{$\begin{array}{l}\text { Average Increase in Paw Volume } \\
(\mathrm{ml}) \pm \text { S.E.M }\end{array}$} \\
\hline & $\begin{array}{l}\text { Pre } \\
\text { dru } \\
\text { g }\end{array}$ & $1 \mathrm{~h}$ & $2 \mathrm{~h}$ & $3 \mathrm{~h}$ & $4 \mathrm{~h}$ & $5 \mathrm{~h}$ & $1 \mathrm{~h}$ & $2 \mathrm{~h}$ & $3 \mathrm{~h}$ & $4 \mathrm{~h}$ & $5 \mathrm{~h}$ \\
\hline $\begin{array}{l}\text { Contro } \\
1\end{array}$ & $\begin{array}{l}2.0 \pm \\
0.02\end{array}$ & $\begin{array}{l}2.8 \pm \\
0.10\end{array}$ & $\begin{array}{l}3.5 \pm \\
0.17\end{array}$ & $\begin{array}{l}4.3 \pm \\
0.18\end{array}$ & $\begin{array}{l}4.2 \pm \\
0.16\end{array}$ & $\begin{array}{l}3.8 \pm \\
0.16\end{array}$ & $\begin{array}{l}0.8 \pm \\
0.07\end{array}$ & $\begin{array}{l}1.5 \pm \\
0.14\end{array}$ & $\begin{array}{l}2.3 \pm \\
0.15\end{array}$ & $\begin{array}{l}2.1 \pm \\
0.13\end{array}$ & $\begin{array}{l}1.8 \pm \\
0.13\end{array}$ \\
\hline $\begin{array}{l}\mathrm{NNF} \\
50 \\
\mathrm{mg} / \mathrm{kg} \\
\end{array}$ & $\begin{array}{l}2.1 \pm \\
0.03\end{array}$ & $\begin{array}{l}3.3 \pm \\
0.21\end{array}$ & $\begin{array}{l}3.9 \pm \\
0.18\end{array}$ & $\begin{array}{l}3.2 \pm \\
0.18^{*} \\
*\end{array}$ & $\begin{array}{l}2.8 \pm \\
0.20 * \\
*\end{array}$ & $\begin{array}{l}2.9 \pm \\
0.21 * \\
*\end{array}$ & $\begin{array}{l}1.2 \pm \\
0.18\end{array}$ & $\begin{array}{l}1.8 \pm \\
0.15\end{array}$ & $\begin{array}{l}1.1 \pm \\
0.15^{*} \\
*\end{array}$ & $\begin{array}{l}0.8 \pm \\
0.16^{*} \\
*\end{array}$ & $\begin{array}{l}0.8 \pm \\
0.18^{*} \\
\end{array}$ \\
\hline $\begin{array}{l}\mathrm{NNF} \\
100 \\
\mathrm{mg} / \mathrm{kg}\end{array}$ & $\begin{array}{l}2.0 \pm \\
0.01\end{array}$ & $\begin{array}{l}2.8 \pm \\
0.10\end{array}$ & $\begin{array}{l}3.1 \pm \\
0.11\end{array}$ & $\begin{array}{l}3.0 \pm \\
0.18 * \\
*\end{array}$ & $\begin{array}{l}2.6 \pm \\
0.07 * \\
*\end{array}$ & $\begin{array}{l}2.5 \pm \\
0.18^{*} \\
*\end{array}$ & $\begin{array}{l}0.7 \pm \\
0.08\end{array}$ & $\begin{array}{l}1.1 \pm \\
0.09\end{array}$ & $\begin{array}{l}1.0 \pm \\
0.16^{*} \\
*\end{array}$ & $\begin{array}{l}0.65 \pm \\
0.05 * \\
*\end{array}$ & $\begin{array}{l}0.48 \pm \\
0.16^{*} \\
*\end{array}$ \\
\hline $\begin{array}{l}\mathrm{NNF} \\
200 \\
\mathrm{mg} / \mathrm{kg}\end{array}$ & $\begin{array}{l}1.9 \pm \\
0.02\end{array}$ & $\begin{array}{l}2.8 \pm \\
0.18\end{array}$ & $\begin{array}{l}3.4 \pm \\
0.14\end{array}$ & $\begin{array}{l}3.0 \pm \\
0.11 * \\
*\end{array}$ & $\begin{array}{l}2.8 \pm \\
0.14 * \\
*\end{array}$ & $\begin{array}{l}2.6 \pm \\
0.16^{*} \\
* \\
\end{array}$ & $\begin{array}{l}0.84 \\
\pm \\
0.15\end{array}$ & $\begin{array}{l}1.43 \\
\pm \\
0.11\end{array}$ & $\begin{array}{l}1 . \overline{11 \pm} \\
0.08 * \\
*\end{array}$ & $\begin{array}{l}0.9 \pm \\
0.11 * \\
*\end{array}$ & $\begin{array}{l}0.66 \pm \\
0.13^{*} \\
*\end{array}$ \\
\hline $\begin{array}{l}\text { Aspiri } \\
\mathrm{n} \\
150 \\
\mathrm{mg} / \mathrm{kg}\end{array}$ & $\begin{array}{l}1.8 \pm \\
0.04\end{array}$ & $\begin{array}{l}1.9 \pm \\
0.05 * \\
*\end{array}$ & $\begin{array}{l}2.1 \pm \\
0.18^{*} \\
*\end{array}$ & $\begin{array}{l}2.3 \pm \\
0.06^{*} \\
*\end{array}$ & $\begin{array}{l}2.1 \pm \\
0.06^{*} \\
*\end{array}$ & $\begin{array}{l}2.0 \pm \\
0.05^{*} \\
*\end{array}$ & $\begin{array}{l}0 . \overline{19} \\
+ \\
0.02\end{array}$ & $\begin{array}{l}0.35 \\
\pm \\
0.14\end{array}$ & $\begin{array}{l}0.5 \pm \\
0.03 * \\
*\end{array}$ & $\begin{array}{l}0.34 \pm \\
0.02 * \\
*\end{array}$ & $\begin{array}{l}0.22 \pm \\
0.01 * \\
*\end{array}$ \\
\hline
\end{tabular}

$n=7$

The expressions were calculated by taking mean \pm standard error to the mean

**p value less than 0.005 was counted as extrem ly significant in comparison to control 
Table 2: Percent inhibition of edema in rats treated with NNF and aspirin

\begin{tabular}{|l|l|l|l|}
\hline \multirow{2}{*}{ Groups } & \multicolumn{3}{|l|}{ \% Inhibition of Edema } \\
\cline { 2 - 4 } & $\mathbf{3 ~ h}$ & $\mathbf{4} \mathbf{~ h}$ & $\mathbf{5} \mathbf{~ h}$ \\
\hline Control & - & - & - \\
\hline $\begin{array}{l}\text { NNF } \\
50 \mathrm{mg} / \mathrm{kg}\end{array}$ & 51.29 & 63.30 & 55.91 \\
\hline $\begin{array}{l}\mathrm{NNF} \\
100 \mathrm{mg} / \mathrm{kg}\end{array}$ & 55.12 & 70.18 & 73.92 \\
\hline $\begin{array}{l}\text { NNF } \\
200 \mathrm{mg} / \mathrm{kg}\end{array}$ & 52.15 & 58.71 & 64.51 \\
\hline $\begin{array}{l}\text { Aspirin } \\
150 \mathrm{mg} / \mathrm{kg}\end{array}$ & 78.44 & 84.40 & 88.17 \\
$n=7$ & &
\end{tabular}

\section{Discussion}

Lots of individuals who experience severe, inexorable and excruciating pain resulting from cancer, injury or from various autoimmune and other degenerative diseases have to rely on opioid medications such as morphine and different non-steroidal anti-inflammatory drugs (NSAIDS) such as aspirin in spite of their established adverse outcomes. Although these synthetic agents are dominating the market but problems of side effects with prolonged use of these agents cannot be ruled out. ${ }^{1,2}$ Hence there is a need to develop new, safe and effective substances with ameliorating effects on inflammation.

Acute inflammation induced by carrageenan is one of the most appropriate techniques to screen agents with anti-inflammatory activity. The time course of edema development in carrageenaninduced hind paw edema model in rats is frequently characterized by a biphasic curve. The initial phase of inflammation arises within an hour of carrageenan injection and is somewhat because of trauma at the injection site and also due to histamine and serotonin element. ${ }^{25}$ The second phase of edema primarily starts from $3^{\text {rd }}$ hour and is sensitive to COX inhibitors such as NSAIDS. ${ }^{3}$ Present study revealed anti-inflammatory activity of NNF which incredibly decreased the paw edema volume at all doses from $3^{\text {rd }}$ to $5^{\text {th }}$ hour as compared to control with maximum percent reduction of edema was calculated at a dose of $100 \mathrm{mg} / \mathrm{kg}$ i.e. $73.92 \%$ at $5^{\text {th }}$ hour after administration of carrageenan. The first phase of the edema i.e. $1^{\text {st }}$ and $2^{\text {nd }}$ hour was not affected by fruit extract. Hence, in present study there was no inhibition of histamine and serotonin at the first phase of the test but cyclooxygenase pathway was effectively inhibited at the second phase of the test.

Flavonoids which are also one of the significant constituents of NNF exert anti-inflammatory effects by several mechanisms; one of them is their proposed capability to diminish neutrophil degranulation. This represents the shortest possible way to inhibit the release of arachidonic acid by neutrophils and other immune cells. Neutrophils containing lipoxygenase produce chemotactic factors from arachidonic acid which also stimulate the release of cytokines. ${ }^{26,27}$ Certain flavonoids are capable of reducing complement activation, thus diminishing the sticking together of inflammatory cells to the endothelium and overall results in a reduced inflammatory response. ${ }^{28}$

Saponins and tannins which are also present in NNF have also reported inhibitory effects on the arachidonic acid metabolism. ${ }^{29}$ Recently conducted study has revealed the analgesic activity of $\mathrm{NNF}$ in various animal models and postulated that it may be connected with the synergistic 
actions of flavonoids, saponins and tannins on arachidonic acid pathway inhibition. ${ }^{30}$ Hence it can be stated that the anti-inflammatory effects of NNF may be due to the presence of flavonoids, saponins and tannins which synergistically exert inhibitory effects on the arachidonic acid metabolism, neutrophil degranulation and on enzyme systems which promote cell growth, proliferation and regulates complement cascade.

\section{Conclusion}

The anti-inflammatory activity of NNF demonstrated in this study were stated to be due to be the presence of secondary metabolites in it which can make it a useful agent in patients suffering from chronic inflammatory disorders but further pre-clinical and clinical evaluation is required to validate these findings.

\section{Conflict of Interest}

The authors declared no conflict of interest.

\section{Acknowledgements}

The authors are thankful to the Chairman Pharmacognosy Department, UOK for identification and authentication of NNF and also appreciate the support of Director, International Center for Chemical and Biological Sciences (ICCBS) for permitting us to use their facilities to complete this piece of work.

\section{References}

1. Yesilada E, Ustun O, Sezik E, Takaishi Y, Ono Y, Honda G. Inhibitory effect of Turkish folk remedies on inflammatory cytokines: Interleukins-1-alpha, interleukins-1-beta and tumor necrosis factor-alpha. J Ethnopharmacol 1997; 58:59-73.

2. Corley DA, Kerlikowske K, Verma R, Buffler P, Protective association of aspirin/NSAIDS and esophageal cancer: A systemic review and meta-analysis. Gastroenterology $2003 ; 124: 47-56$.

3. Singh M, Kumar V, Singh I, Gauttam V, Kalia AN. Anti-inflammatory activity of aqueous extract of Mirabilis jalapa Linn. leaves. Pharmacognosy Res 2010; 2:364-67.

4. Leonardo DCL, Franco A, Gustavo ATL, Luciano MA, Lius FMES, Gabriele PDS et al. Toxicol. Lett 2000; 116:189-198.

5. Agbaje EO, Adeneye AA, Daramola AO. Biochemical and toxicological studies of aqueous extract of Syzigium aromaticum L. Merr. \& Perry Myrtaceae in rodents. Afr J Trad CAM 2009; 6:3, 241-54.

6. Mukherjee PK, Mukherjee D, Maji AK, Rai S, Mukherjee PK, Saha K et al. The sacred lotus (Nelumbo nucifera) phytochemical and therapeutic profile. Journal of Pharmacy and Pharmacology 2009; 61:407-22. PMID:19298686

7. Sridhar KR, Bhat R. Lotus: a potential nutraceutical source. J Agri Technol 2007; 3:14355.

8. Carlo FM, Masami Y, Yoshiaki K, Ganesh KA, Randeep Rakwal. Lotus - A Source of Food and Medicine: Current Status and Future Perspectives in Context of the Seed Proteomics, IJLS 2013; 7:1-5.

9. Indrayan AK, Sharma S, Durgapal D, Kumar N, Kumar M. Determination of nutritive value and analysis of mineral elements for some medicinally valued plants from Uttaranchal. Curr Sci 2005; 89: 1252-1255.

10. Pal I, Dey P. A review on lotus (Nelumbo nucifera) seed. International Journal of Science and Research 2015; 4:1659-66. 
11. Rajput MA, Khan RA. Phytochemical screening, acute toxicity, anxiolytic and antidepressant activities of Nelumbo nucifera fruit. Metab Brain Dis 2017; 32(3):743-749. DOI 10.1007/s11011-017-9963-x

12. Chopra RN, Chopra IC, Nayar SL. Glossary of Indian Medicinal Plants. New Delhi: Council of Scientific and Industrial Research 1996; 174.

13. Varshney CK, Rzoska J. Aquatic weeds in South East Asia. $1^{\text {st }}$ ed. New Delhi: Springer; 1976; p. 39.

14. Rajput MA, Khan RA and Assad T. Anti-epileptic activity of Nelumbo nucifera fruit. Metab Brain Dis 2017; 32: 1883-87. DOI: 10.1007/s11011-017-0064-7.

15. National Advisory Committee for Laboratory Animal Research. Guidelines on th care and use of animals for scientific purposes. 2004; p. 24.

16. National Institute of Health Guidelines for Care and Use of Laboratory Animals in Biomedical Research. Guide for the care and use of laboratory animals. Prepublication draft. $8^{\text {th }}$ ed. The National Academies Press Washington DC 2010; 6, 47.

17. Hossain MS, Ahmed M, Islam A. Hypolipidemic and hepatoprotective effects of different fractions of ethanolic extract of immature leaves of Mangifera indica Linn in alloxan induced diabetic rats. Journal of Pharmaceutical Sciences and Research 2010; 1:13238 .

18. Assad T, Khan RA, Rajput MA. Effect of Trigonella foenum-graecum Linn seeds methanol extract on learning and memory. Metab Brain Dis 2018; 33:1275-80. doi: 10.1007/s11011-018-0235-1

19. Madhu A, Keerthi PHV, Singh J, Shivalinge GKP. To evaluate the anti-epileptic activity of aqueous root extract of Hemidesmus indicus in rats. Arch. Pharm. Sci. Res 2009; 1: 43-7.

20. Khan RA, Rajput MA, Assad T. Effect of Nelumbo nucifera fruit on scopolamine induced memory deficits and on motor coordination. Metab Brain Dis 2018; 34:87-92. https://doi.org/10.1007/s11011-018-0324-1. Epub 2018 Oct 1.

21. Ocete MA, Risco S, Zarzuelo A, Jimenez J. Pharmacological activity of the essential oil of Bupleurum gibraltaricum: anti-inflammatory activity and effects on isolated rat uteri. J Ethnopharmacol 1989;25:305-13

22. Ahmed S, Naved A, Khan RA, Siddiqui S. Analgesic Activities of Methanol Extract of Terminalia chebula Fruit. Pharmacology \& Pharmacy 2015; 6:547-53.

doi:10.4236/pp.2015.612056

23. Winter CA, Risely EA, Nuss GW. Carrageenan induced edema in hind paw of the rat as an assay for antiinflammatory drugs. Proc. Soc. Exp. Biol. Med 1962; 111: 544-47.

24. Palanichamy S, Nagarajan S. Anti-inflammatory activity of Cassia alata leaf extract and kaempferol 3-O-sophoroside. Fitoterapia 1990; 61: 44-7.

25. Crunkhorn P, Meacock SC. Mediators of the inflammation induced in the rat paw by Carrageenan. Br J Pharmacol 1971; 42:392-402.

26. Hoult JR, Moroney MA, Paya M. Actions of flavonoids and coumarins on lipoxygenase and cyclooxygenase. Methods Enzymol 1994; 234:443-54.

27. Tordera M, Ferrandiz ML, Alcaraz MJ. Influence of anti-inflammatory flavonoids on degranulation and arachidonic acid release in rat neutrophils. Z Naturforsch [C] 1994; 49:235-40.

28. Friesenecker B, Tsai AG, Intaglietta M. Cellular basis of inflammation, edema and the activity of Daflon 500 mg. Int J Microcirc Clin Exp 1995; 15(suppl):17-21. 
29. Ahmadiani A, Hosseiny J, Semnanian S, Javan M, Saeedi F, Kamalinejad M et al. Antinociceptive and anti-inflammatory effects of Eleagnusangusti folia Fruit Extract. $J$ Ethnopharmacol 2000; 72:287-92.

30. Rajput MA, Tabassum, Z, Fizzah A, Gunesh K. Assessment of analgesic activity of Nelumbo nucifera fruit ethanol extract. Int J PharmSci, 2019; 11:1-5.

https://doi.org/10.22159/ijpps.2019.35455 